\title{
An aqueous extract of green tea Camellia sinensis increases expression of Th1 cell-specific anti-asthmatic markers
}

\author{
JIN-CHUL HEO ${ }^{1,2}$, JAE RANG RHO ${ }^{2}$, TAE-HO KIM ${ }^{3,5}$, SHIN-YOON KIM $^{4,5}$ and SANG-HAN LEE ${ }^{1,6}$ \\ ${ }^{1}$ Food and Bio-Industry Research Institute, Kyungpook National University, Daegu 702-701; ${ }^{2}$ Department of Bioscience \\ and Biotechnology, Chungnam National University, Daejeon 305-764; Departments of ${ }^{3}$ Medicine, and ${ }^{4}$ Orthopedic \\ Surgery, Kyungpook National University School of Medicine, Daegu 700-422; ${ }^{5}$ Skeletal Diseases Genome Research Center, \\ Kyungpook National University Hospital, Daegu 700-412; ${ }^{6}$ Department of Food Science and \\ Biotechnology, Kyungpook National University, Daegu 702-701, Korea
}

Received August 11, 2008; Accepted September 25, 2008

DOI: 10.3892/ijmm_00000083

\begin{abstract}
The present study provides evidence of the antiasthmatic signaling activity of an aqueous fraction of green tea using specific in vitro and in vivo assays in an ovalbumininduced asthmatic model. Mice sensitized to ovalbumin were orally administered an aqueous extract of Camellia sinensis. The lungs of these mice were then examined by hematoxylin and eosin staining and ELISA analysis to measure cytokine expression. The aqueous extract of Camellia sinensis exhibited potent anti-asthmatic activity by increasing the expression level of tumor necrosis factor- $\beta$ and interferon- $\gamma$ and decreasing the expression of anti-asthmatic cytokines in the lung. Together, these results indicate that the aqueous fraction of Camellia sinensis is effective in alleviating asthmatic symptoms by increasing the expression of Th1 cell-specific anti-asthmatic biomarkers.
\end{abstract}

\section{Introduction}

Camellia sinensis (Cs) or green tea is a well-known plant in the production of traditional and medicinal plant drinks throughout the world. Green tea is considered one of the most popular table drinks because Cs contains polyphenolic tannins, calcium, iodine, and ferrous ions (1). Cs also has a beneficial effect on immunomodulatory activity that is attributed to dietary fibers and specific polyphenols (2). The polyphenolic compounds in tea demonstrate potential anti-

Correspondence to: Professor Sang-Han Lee, Department of Food Science and Biotechnology, Graduate School, Kyungpook National University, Daegu 702-701, Korea

E-mail: sang@knu.ac.kr

Abbreviations: Cs, Camellia sinensis; MMP, matrix metalloproteinase; IL, interleukin; OVA, ovalbumin; EGCG, epigallocatechin-3-gallate; IFN, interferon; TNF, tumor necrosis factor

Key words: Camellia sinensis, biomarkers, aqueous extract, ovalbumin-challenge model tumor and anti-oxidant effects in various cancer cell lines, including gastric, colon, and lung (3).

In an early report, tea debris was shown to increase the symptoms of asthma (4). Thereafter, in 1994, it was revealed that epigallocatechin-3-gallate (EGCG), a polyphenol, is a key mediator of asthma and the main causative agent of green tea-induced asthma (5). Another report revealed that EGCG induces histamine release in patients with green-teainduced asthma-related disorders (6) and shows a significant correlation between the maximum percentage of histamine release and the threshold level of EGCG for intradermal skin testing. In some cases, potent anti-oxidant activity may increase the likelihood of developing allergic diseases and asthma (7). In conflicting studies, gallic acid and EGCG in tea were found to alleviate allergen-induced asthma and atopic dermatitis in in vitro and in vivo models (8-10).

In the present study, in the course of screening potent anti-asthmatic agents from natural sources, we found that the aqueous fraction of green tea had potential in alleviating asthmatic symptoms in vivo. The major finding of this study is that Cs exhibits anti-asthmatic activity in vivo by increasing the level of expression of tumor necrosis factor- $\beta$ and interferon- $\gamma$ and by reducing the expression of asthmaticrelated IL-4 and IL-13.

\section{Materials and methods}

Animal care and experiments. Animal experiments were performed using mice weighing $25.5 \pm 2.5 \mathrm{~g}$ (Balb/c, male, Samtaco, Osan, Korea). Each mouse was housed in a single cage, and each group consisted of 5 mice. Animal care was performed as described previously $(11,12)$. All procedures were performed in compliance with the Guiding Principles in the Care and Use of Animals (National Research Council, 1996) of the Animal Welfare Committee of Kyungpook National University. Animals received tap water and food ad libitum, and were maintained in a room under standard laboratory conditions $\left(23^{\circ} \mathrm{C} \pm 1^{\circ} \mathrm{C}\right.$ and $50 \pm 5 \%$ humidity) with a 12 -h dark/light cycle. The animal experiments, including ethical care, were performed under the strict guidance of the Animal Welfare Committee. 
Table I. Oligonucleotide primers used for PCR reactions.

\begin{tabular}{|c|c|c|c|}
\hline Name & \multicolumn{2}{|l|}{ Sequence of forward $(F)$ or reverse $(R)$ primer } & Length (bp) \\
\hline \multirow[t]{2}{*}{ TNF- 3} & 5'-TTCСТСССАATACСССТTCC-3' & $\mathrm{F}$ & 387 \\
\hline & 5'-TTGAGTTCGTCCCCCTGAGCA-3' & $\mathrm{R}$ & \\
\hline \multirow[t]{2}{*}{$\mathrm{INF}-\gamma$} & 5'-AGCGGCTGACTGAACTCAGAT-3' & $\mathrm{F}$ & 244 \\
\hline & 5'-GTCACAGTTTTCAGCTGTATAGGG-3' & $\mathrm{R}$ & \\
\hline \multirow[t]{2}{*}{ IL-10 } & 5'-CACTGCTATGCTGCCTGCTC-3' & $\mathrm{F}$ & 417 \\
\hline & 5'-TCTTCACCTGCTCCACTGCC-3' & $\mathrm{R}$ & \\
\hline \multirow[t]{2}{*}{ GAPDH } & 5'-ATGTTCCAGTATGACTCCAC-3' & $\mathrm{F}$ & 361 \\
\hline & 5'-GCCAAAGTTGTCATGGATGA-3' & $\mathrm{R}$ & \\
\hline
\end{tabular}

Preparation and fractionation of samples. Cs was obtained from a farm (SsangGyeJeDa) in Hadong, Kyungnam, Korea. The young leaves were incubated in an oven at $60^{\circ} \mathrm{C}$ for $12 \mathrm{~h}$, and then methanol extraction was performed on the dried leaves $(1: 1 ; \mathrm{v} / \mathrm{v})$ for $18 \mathrm{~h}$. The methanol extract was centrifuged at 2,000 x g for $10 \mathrm{~min}$ and the supernatant fractions were collected and stored at $-70^{\circ} \mathrm{C}$ until required. The supernatant fractions were freeze-dried and solubilized in methanol for in vivo assays. The samples were harvested from early to the middle of April 2006, and were identified by a senior staff member of the Kyungpook National University, Daegu, Korea. Voucher specimens of the plant were deposited in the Enzyme Biotechnology Lab, KNU.

Ovalbumin-induced animal model. Mice underwent ovalbumin (OVA) sensitization and challenge with Cs using previously described protocols with slight modifications (1315). In brief, OVA $(100 \mu \mathrm{g} / \mathrm{ml}$ in a saline, sterile-filtered) was mixed with an equal volume of $10 \%(\mathrm{w} / \mathrm{v})$ aluminum potassium phosphate (alum; Sigma), and its $\mathrm{pH}$ level adjusted to 6.5 with $10 \mathrm{~N} \mathrm{NaOH}$. Mice were sensitized by intraperitoneal injection with $100 \mu \mathrm{g} / \mathrm{ml} \mathrm{OVA}$ on days 0,7 , and 14 , followed by exposure to aerolized OVA or phosphate-buffered saline for $1 \mathrm{~h}$ on days 21 and 24. From day 14 , oral administration with Cs extract $(25 \mu \mathrm{g} / \mathrm{ml})$ followed every 2 days for 2 weeks, thereafter histopathological examination of tissue samples was analyzed. Mice were analyzed by hematoxylin and eosin (H-E) and Periodic Acid Schiff (PAS) staining and by immunohistochemical analysis, as described previously (12). All data were expressed as a mean \pm standard deviation.

Reverse-transcription polymerase chain reaction analysis. Total RNA was prepared from $\sim 100 \mathrm{mg}$ of lung tissue that was lysed and homogenized in $1 \mathrm{ml}$ TRIzol ${ }^{\circledR}$ Reagent (16). The total RNA was quantified by spectrophotometry at $260 \mathrm{~nm}$ (VICTOR3 spectrophotometer; Perkin Elmer, Wellesley, MA), and the RNA quality was examined by $1 \%$ agarose gel electrophoresis and ethidium-bromide staining. The RNA samples were then stored at $-80^{\circ} \mathrm{C}$ until required. The primers, which were synthesized by Bioneer Co. (Daejeon, Korea), are listed in Table I. Briefly, the first-strand of cDNA was reverse-transcribed from $500 \mathrm{ng}$ of total RNA at $45^{\circ} \mathrm{C}$ for $30 \mathrm{~min}$, the samples were denatured for $5 \mathrm{~min}$ at $95^{\circ} \mathrm{C}$, and PCR amplification was performed with 32 cycles (TNF- $\beta$ and IFN- $\gamma$ ), 35 cycles (IL-10) or 27 cycles (GAPDH) of $45 \mathrm{sec}$ at $94^{\circ} \mathrm{C}$ followed by $45 \mathrm{sec}$ at $57^{\circ} \mathrm{C}$ for TNF- $\beta, \mathrm{IFN}-\gamma$, and GAPDH or $55^{\circ} \mathrm{C}$ for IL-10, and then $60 \mathrm{sec}$ at $72^{\circ} \mathrm{C}$. After amplification, $20 \mu 1$ of each RT-PCR product was resolved by $1.5 \%$ agarose gel electrophoresis and visualized by ethidium-bromide staining. The predicted product was confirmed by comparison with a 1-kb DNA ladder (Solgent, Daejeon, Korea). The relative amounts of cDNA were normalized with respect to GAPDH expression using the Molecular Imager Gel Doc XR System and Quantity One 1-D analysis software (Bio-Rad, Philadelphia, PA) as previously described $(17,18)$.

Immunohistochemistry and histopathology. Tissues were embedded in paraffin, cut into sections 4-6 $\mathrm{mm}$, and set overnight on a slide warmer at $37^{\circ} \mathrm{C}$. Paraffin was removed by dipping slides in xylene three times for $10 \mathrm{~min}$. Xylene was removed by passing sections through serial dilutions of ethanol from $70-100 \%$ for $60 \mathrm{~min}$. After washing, and peroxidase bleaching, $\mathrm{H}-\mathrm{E}$ staining was performed as previously described $(19,20)$. Lung tissues were fixed for $24 \mathrm{~h}$ in a $10 \%$ neutral buffered formalin solution, and processed for immunohistochemical analysis. Tissue sections were treated with $10 \%$ normal goat serum for $1 \mathrm{~h}$ at room temperature to block non-specific binding. Slides were subsequently incubated overnight at $4^{\circ} \mathrm{C}$ with rabbit anti-IL-4, anti-IL-13, or CD4 antibody (SantaCruz Biotechnology; $1: 200)(12,13)$. PAS staining was performed using previously described protocols (20).

Statistical analysis. Statistical significance was calculated using the Student's t-test method for independent means and the Microsoft Excel program (21). The critical level for significance was set at $\mathrm{p}<0.05$.

\section{Results and discussion}

The anti-asthmatic activity of the aqueous fraction of Cs was investigated in vivo using an ovalbumin (OVA)-induced asthmatic mouse model. Mice were sensitized by intraperitoneal injection with $100 \mu \mathrm{g} / \mathrm{ml} \mathrm{OVA}$ on days 0,7 , and 


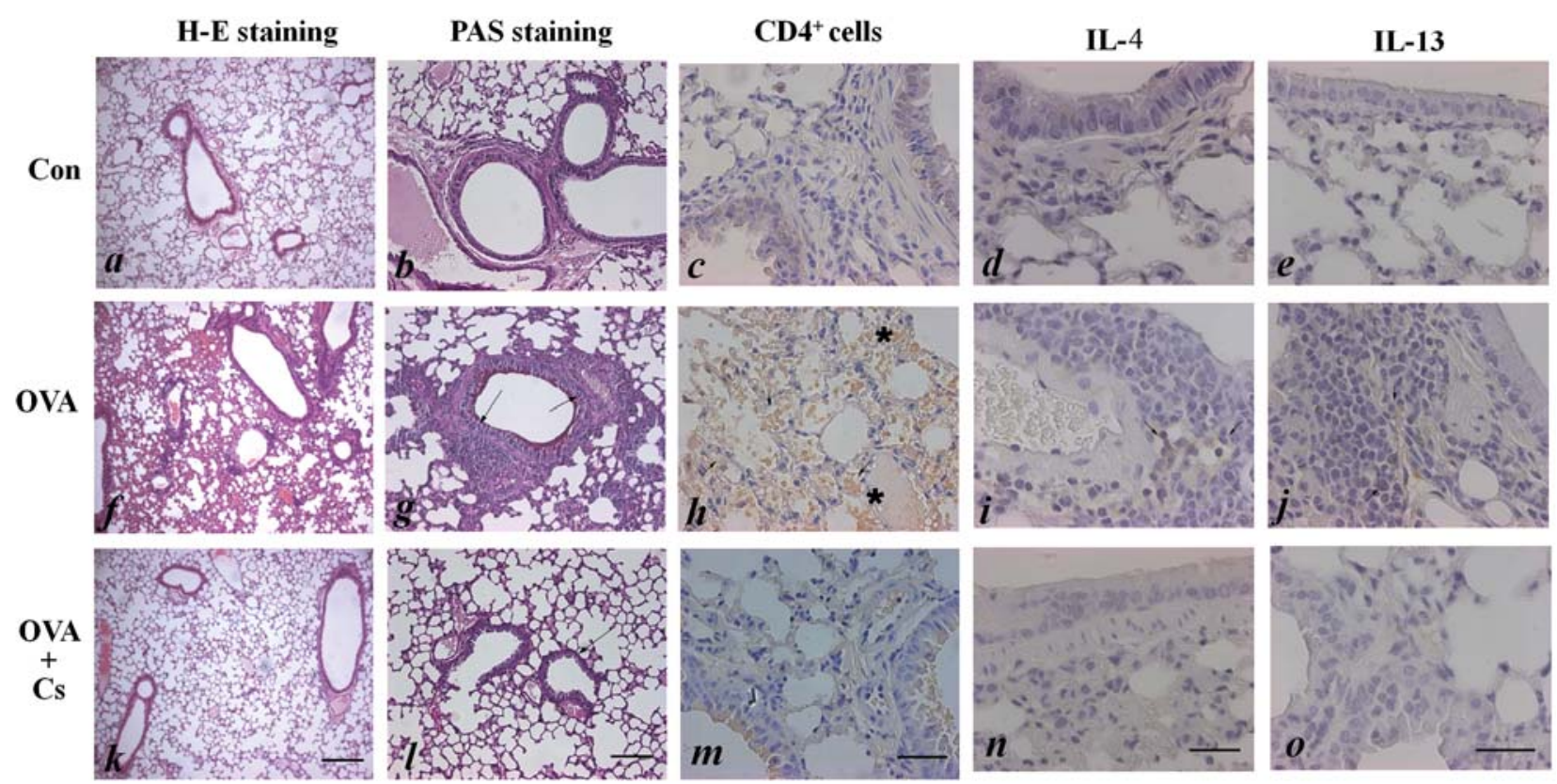

Figure 1. Immunological analysis showing alleviation of asthmatic symptoms by an aqueous extract of Camellia sinensis. Immunohistochemical analysis of an OVA-induced asthmatic mouse model demonstrated that an aqueous extract of Cs reduces the level of CD4+ cells by controlling immune cell proliferation. CD4 ${ }^{+}$cells $(f$ and $i)$, HE-stained ( $d$ and $g$ ), and PAS-positive ( $e$ and $h$ ) cells in lung tissue of OVA-induced asthmatic mice with or without treatment with Cs extract. A section of the tissue is shown to represent the immune response and the distribution of asthma-related immune cells $($ arrowhead, scale bar $=50 \mu \mathrm{m})$. OVA, treatment with ovalbumin $100 \mu \mathrm{g} / \mathrm{ml} ; \mathrm{Cs}, 25 \mu \mathrm{g} / \mathrm{ml}$ of the aqueous extract of Camellia sinensis. Asterisks denote CD4+-expressing ( $h$ ), IL-4 (i), or IL-13 (j) cells.

(A)

(B)

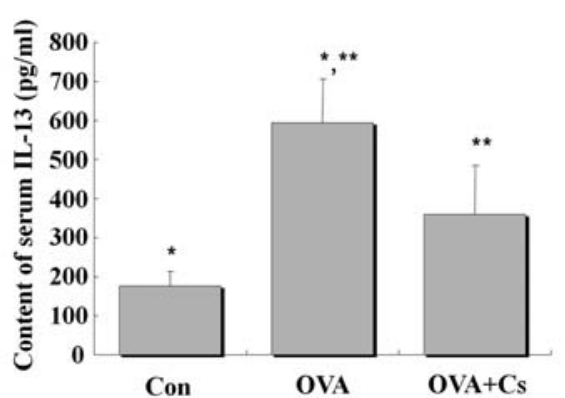

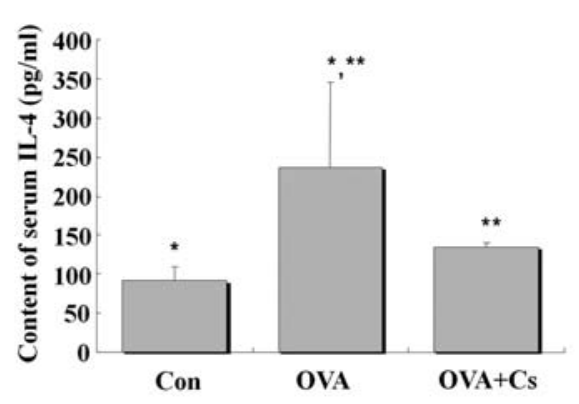

(C)

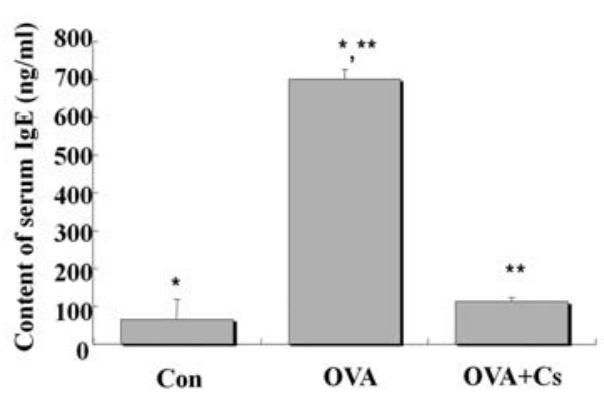

Figure 2. Inhibitory effects of an aqueous extract of Camellia sinensis on OVA-challenged asthmatic mice. Serum IL-4 (A), IL-13 (B), and IgE (C) levels were determined using ELISA, as described previously (12). OVA, ovalbumin treated (100 $\mu \mathrm{g} / \mathrm{ml})$; Cs, $25 \mu \mathrm{g} / \mathrm{ml}$ of aqueous extract of Camellia sinensis. ${ }^{*}$ Significant difference compared with control, $\mathrm{p}<0.05 .{ }^{* *}$ Significant difference compared with OVA, $\mathrm{p}<0.05$.

14, followed by exposure to aerolized OVA or phosphatebuffered saline for $1 \mathrm{~h}$ on days 21 , and 24 (data not shown). In these experiments, mice in the test group were orally administered the aqueous fraction of $\mathrm{Cs}(25 \mu \mathrm{g} / \mathrm{ml})$ on day 14 and every 2 days for 2 weeks. The tissues of test and control mice were prepared for immunohistopathological analyses. 


\section{Con OVA OVA+Cs}

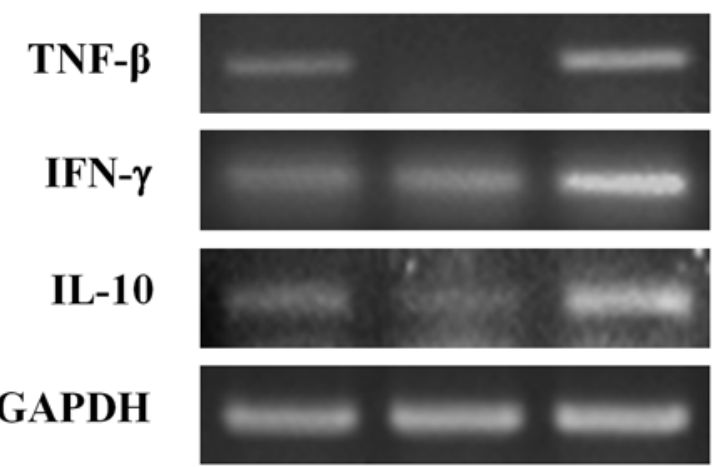

Figure 3. RT-PCR analysis of the expression profiles of TNF- $\beta$, IFN- $\gamma$, and IL-10 in lung tissues. The lung tissues were prepared and lysed for the isolation of RNA. The PCR primers were designed and the detailed procedures are shown as described previously (12). OVA, ovalbumin treated $(100 \mu \mathrm{g} / \mathrm{ml}) ; \mathrm{Cs}, 25 \mu \mathrm{g} / \mathrm{ml}$ of an aqueous extract of Camellia sinensis.

H-E staining showed no staining of cells in the tissue of untreated mice (Fig. 1a). By comparison, ovalbumin-treated lung tissue showed many immune-positive cells around epithelial cells (Fig. 1f). PAS analysis revealed similar patterns (Fig. $1 b$ and $g$ ). These results strongly suggest that, as expected, OVA treatment induces asthmatic symptoms in the model system, resulting in the potential for strong mucus production (Fig. $1 g$, arrows, and data not shown). The administration of aqueous extracts of Cs at $25 \mu \mathrm{g} / \mathrm{ml}$ resulted in a reduction in the number of immune-positive cells (Fig. 1k). The arrow head shown in Fig. $1 l$ reveals indirectly that mucus production was markedly reduced in the lung tissues. The total number of immune cells was markedly lower in the group treated with $\mathrm{Cs}$ than in the group with OVA-challenged lung tissues (Fig. $1 k$ and $l$ ).

In asthma, the status of the Th1 and Th2 cell populations has a pivotal role in immune cell differentiation by modulating the balance of the immune cell population. Th 1 cell populations have a higher number of $\mathrm{CD}^{+}{ }^{+}$cells than $\mathrm{CD}^{+}$ cells, and the opposite is seen for Th2 cell populations. For this reason, the balance of the Th1 and Th2 cell numbers is important for the homeostasis in the human body. In the present study, we performed immunohistochemical analyses using a CD4 monoclonal antibody to determine whether $\mathrm{CD}^{+}{ }^{+}$was expressed in immune cells associated with lung tissues. The total number of $\mathrm{CD}^{+}$cells in control mice was very low compared with the number of $\mathrm{CD}^{+}$cells in tissue samples of OVA-challenged mice (asterisks in Fig. 1h). By comparison, Cs treatment markedly reduced the number of $\mathrm{CD} 4^{+}$cells (Fig. $1 \mathrm{~m}$ ), which is consistent with the pattern of expression indicated by $\mathrm{H}-\mathrm{E}$ analysis (Fig. $1 f$, and $k$ ) and PAS staining (Fig. $1 g$, and $l$ ). Similarly, immunohistochemical analyses revealed a marked reduction in the number of IL-4-positive cells in tissue samples from the Cs-treated group compared with the number of IL-4-positive cells in equivalent samples from the OVA-challenged group (asterisks in Fig. 1i). The expression of IL-13 is also markedly reduced in Cs-treated tissues compared with OVAinduced tissues (Fig. $1 j$ and $o$ ).

To confirm our finding that asthma-related cytokines decrease as a result of Cs treatment, the expression levels of
IL-4 and/or IL-13, along with the level of IgE, were measured by ELISA $(12,22)$. The serum level of IL-4 was $91.5 \pm 20.9 \mathrm{pg} / \mathrm{ml}$ in the control group and $235.1 \pm 98.9 \mathrm{pg} / \mathrm{ml}$ in the OVA alone group. This 2.5-fold increase in the level of IL-4 may be associated with the OVA-induced response of the immune cells. Treatment with an aqueous extract of Cs decreased the IL-4 level to $\sim 45 \%$ of the level found in OVA alone group (Fig. 2A). We observed a 52\% decrease in the level of IL-13 expression in the group treated with OVA plus Cs (Fig. 2B). As confirmed by IgE expression levels, ELISA analysis revealed that $\mathrm{Cs}$ induces a decrease in the expression of asthma-related molecular markers in the OVA-challenged mouse model by $\sim 77 \%$ (Fig. 2C). We assessed the expression of TNF- $\beta$, IFN- $\gamma$, and IL- 10 by RT-PCR in the OVAchallenged group and the Cs-treated group (Fig. 3). It is known that the Th cell population expresses high levels of TNF- $\alpha$ and TGF- $\beta 1$ (23-25). To investigate the mechanisms underlying the involvement of TNF- $\alpha$ and $\beta$ in the Th1 cell population, we examined the expression levels of TNF- $\alpha$ and $\beta$ mRNA. As shown in Fig. 3, notably, OVA-exposure induced classical asthmatic symptoms in mice resulting in the down-regulation of TNF- $\beta$ expression (lane 1). This phenomenon is also confirmed by the expression of IFN- $\gamma$ and IL-10 (Fig. 3, lanes 2 and 3). Treatment with the Cs extract reversed the OVA-induced down-regulation of TNF- $\beta$ (Fig. 3, lane 1). By comparison, the expression of IFN- $\gamma$ and IL-10 was up-regulated by treatment with the Cs extract by 2.56- and 5.73- fold, respectively (Fig. 3, lanes 2 and 3).

It is well-known that green-tea extract has potential activity against tumor progression and immune diseases by triggering the immunomodulatory signaling network (26). Although anti-asthmatic markers are associated with specific cytokines in immunologically stimulated cells (27), the relationship between anti-asthmatic markers and cytokines remains unclear. For this reason, we investigated the effect of green-tea extract on the homeostatic balance of immune cells during the onset of asthma via Th1 and Th2 cells. The present data show that green tea extract alleviates asthmatic symptoms by inducing an increase in Th1-cell-specific biomarkers and by decreasing the expression of Th2-cellspecific cytokines. The cytokines IL-17 and IL-31 are expressed during the asthmatic response in immunestimulated cells (28). In the present study, we found no difference in the levels of expression of IL-17 and IL-31 by RT-PCR analysis between the OVA-treated group and the Cs-treated group (data not shown).

In summary, we demonstrated that an aqueous extract of Cs exerts anti-asthmatic activity by alleviating asthmarelated cytokine activity through increasing the expression level of TNF- $\beta$ and IFN- $\gamma$ and by decreasing the expression level of anti-asthmatic cytokine IL-4 and IL-13 in the lungs. Investigations into the precise mechanisms underlying the asthmatic response either by manipulation of anti-asthmatic activity or by amelioration of asthma-related molecular signals, may lead to the development of new anti-asthmatic agents, including those of food-based origin. The present study highlights the need for future investigations to focus on the collection and purification of potential anti-asthmatic compounds or components from Cs extracts for eventual therapeutic application. 


\section{Acknowledgements}

This study was supported by a grant from the Korea Health 21 R\&D Project, Ministry of Health \& Welfare, Republic of Korea (Project No. A010252). This study was also supported partially by the Technology Development Program for Agriculture and Forestry, Ministry of Agriculture and Forestry, Republic of Korea.

\section{References}

1. Cabrera C, Artacho R and Giménez R: Beneficial effects of green tea: a review. J Am Coll Nutr 25: 79-99, 2006.

2. Monobe M, Ema K, Kato F and Maeda-Yamamoto M: Immunostimulating activity of a crude polysaccharide derived from green tea (Camellia sinensis) extract. J Agric Food Chem 56: $1423-1427,2008$

3. Sliva D: Suppression of cancer invasiveness by dietary compounds. Mini Rev Med Chem 8: 677-688, 2008.

4. Cartier A and Mal JL: Occupational asthma due to tea dust. Thorax 45: 203-206, 1990.

5. Shirai T, Sato A and Hara Y: Epigallocatechin gallate. The major causative agent of green tea-induced asthma. Chest 106: 1801-1805, 1994

6. Shirai T, Reshad K, Yoshitomi A, Chida K, Nakamura H and Taniguchi M: Green tea-induced asthma: relationship between immunological reactivity, specific and non-specific bronchial responsiveness. Clin Exp Allergy 33: 1252-1255, 2003.

7. Murr C, Schroecksnadel K, Winkler C, Ledochowski M and Fuchs D: Antioxidants may increase the probability of developing allergic diseases and asthma. Med Hypotheses 64: 973-977, 2005.

8. Bani D, Giannini L, Ciampa A, Masini E, Suzuki Y, Menegazzi M, Nistri S and Suzuki H: Epigallocatechin-3-gallate reduces allergen-induced asthma-like reaction in sensitized guinea pigs. J Pharmacol Exp Ther 317: 1002-1011, 2006.

9. Kim SH, Park HJ, Lee CM, Choi IW, Moon DO, Roh HJ, Lee HK and Park YM: Epigallocatechin-3-gallate protects toluene diisocyanate-induced airway inflammation in a murine model of asthma. FEBS Lett 580: 1883-1890, 2006.

10. Ki SH, Jun CD, Suk K, Choi BJ, Lim H, Park S, Lee SH, Shin HY, Kim DK and Shin TY: Gallic acid inhibits histamine release and pro-inflammatory cytokine production in mast cells. Toxicol Sci 91: 123-131, 2006.

11. Hwang YK, Chun JS, Yoo PD, Ma JY, Hyun BH, Kim SU, Chang KT and Lee SH: Occlusal reduction of unilateral molars influences change of stress-related hormones in rats. Scand J Lab Anim Sci 31: 73-77, 2004.

12. Heo JC, Woo SW, Kweon MA, Park JY, Lee HK, Son M, Rho JR and Lee SH: Aqueous extract of the Helianthus annuus seed alleviates asthmatic symptoms in vivo. Int J Mol Med 21: 57-61, 2008.

13. Wu AY, Chik SC, Chan AW, Li Z, Tsang KW and Li W: Antiinflammatory effects of high-dose montelukast in an animal model of an acute asthma. Clin Exp Allergy 33: 359-366, 2003.
14. Lee E, Ha K, Yook JM, Jin MH, Seo CS, Son KH, Kim HP, Bae KH, Kang SS, Son JH and Chang HW: Anti-asthmatic activity of an ethanol extract from Saururus chinensis. Biol Pharm Bull 29: 211-215, 2006.

15. Choi JH, Oh SW, Kang MS, Kwon HJ, Oh GT and Kim DK: Trichostatin A attenuates airway inflammation in mouse asthma model. Clin Exp Allergy 35: 89-96, 2005.

16. Roos-van Groningen MC, Eikmans M, Baelde HJ, de Heer E and Bruijn JA: Improvement of extraction and processing of RNA from renal biopsies. Kidney Int 65: 97-105, 2004.

17. An SM, Park CH, Heo JC, Park JY, Woo SW, Seo JH, Lee MS, Cho KJ, Cho HS, Shin HM and Lee SH: Gastrodia elata Blume protects against stress-induced gastric mucosal lesions in mice. Int J Mol Med 20: 209-215, 2007.

18. Heo JC, Park JY, Woo SU, Rho JR, Lee HJ, Kim SU, Kho YH and Lee SH: Dykellic acid inhibits cell migration and tube formation by RhoA-GTP expression. Biol Pharm Bull 29: 2256-2259, 2006.

19. Kim DY, Ryu SY, Lim JE, Lee YS and Ro JY: Anti-inflammatory mechanism of simvastatin in mouse allergic asthma model. Eur J Pharmacol 557: 76-86, 2007.

20. Ponikau JU, Sherris DA, Kephart GM, Kern EB, Gaffey TA, Tarara JE and Kita H: Features of airway remodeling and eosinophilic inflammation in chronic rhinosinusitis: is the histopathology similar to asthma? J Allergy Clin Immunol 112: 877-882, 2003

21. Falkeholm L, Grant CA, Magnusson A and Moller E: Xylenefree method for histological preparation: a multicentre evaluation. Lab Invest 81: 1213-1221, 2001

22. Striz I, Mio T, Adachi Y, Robbins RA, Romberger DJ and Rennard SI: IL-4 and IL-13 stimulate human bronchial epithelial cells to release IL-8. Inflammation 23: 545-555, 1999.

23. Kelly L, McCan KL and Imani F: Transforming growth factor beta enhances respiratory syncytial virus replication and tumor necrosis factor- $\alpha$ induction in human epithelial cells. J Virol 81: 2880-2886, 2007

24. Wegmann M, Fehrenbach H, Fehrenbach A, Held T, Schramm C, Garn $\mathrm{H}$ and Renz $\mathrm{H}$ : Involvement of distal airways in a chronic model of experimental asthma. Clin Exp Allergy 35: 1263-1271, 2005.

25. Gentile DA, Doyle WJ, Zeevi A, Howe-Adams J, Trecki J and Skoner DP: Association between TNF-alpha and TGF-beta genotypes in infants and parental history of allergic rhinitis and asthma. Hum Immunol 65: 347-351, 2004

26. Clarke JO and Mullin GE: A review of complementary and alternative approaches to immunomodulation. Nutr Clin Pract 23: 49-62, 2008

27. Brightling C, Berry M and Amrani Y: Targeting TNF- $\alpha$, a novel therapeutic approach for asthma. J Allergy Clin Immunol 121: $5-10,2008$

28. Lei Z, Liu G, Huang Q, Lv M, Zu R, Zhang GM, Feng ZH and Huang B: SCF and IL-31 rather than IL-17 and BAFF are potential indicators in patients with allergic asthma. Allergy 63: 327-332, 2008. 